Article

\title{
Economic Voting in EU Referendums: Sociotropic versus Egocentric Voting in the Lisbon Treaty Plebiscites in Ireland
}

\author{
Johan A. Elkink ${ }^{1}$, Stephen Quinlan ${ }^{2, *}$ and Richard Sinnott ${ }^{1,3}$ \\ ${ }^{1}$ School of Politics and International Relations, University College Dublin, Belfield, Dublin, Ireland; \\ E-Mails: jos.elkink@ucd.ie (J.A.E.),richard.sinnott@ucd.ie (R.S.) \\ ${ }^{2}$ Department of Monitoring Society and Social Change, GESIS-Leibniz Institute for the Social Sciences, 68159 Mannheim, \\ Germany; E-Mail: stephen.quinlan@gesis.org \\ ${ }^{3}$ UCD Geary Institute for Public Policy, University College Dublin, Belfield, Dublin, Ireland \\ * Corresponding author
}

Submitted: 22 December 2018 | Accepted: 13 April 2019 | Published: 27 June 2019

\begin{abstract}
Economic voting is one of the most studied aspects of electoral behaviour. The dominant view is that sociotropic economic considerations are more important to voters in national elections. However, other research suggests that utilitarian motivations are key to understanding support for the EU. An EU integration referendum offers the opportunity to explore whether and when sociotropic or utilitarian motivations are more important in determining vote choice. The unusual combination of two successive referendums in Ireland on the Lisbon Treaty, either side of the Global Financial Crisis, provides the ideal opportunity to test these assumptions. Using data from two post-referendum surveys, we demonstrate that the economy mattered in both referendums but that different economic motivations drove vote choice in each, with sociotropic motivations more critical as a result of the Global Financial Crisis. Our study has implications for economic voting and referendums and demonstrates that context is crucial in determining a voter's economic motivations in a plebiscite.
\end{abstract}

\section{Keywords}

economic voting; egocentric voting; financial crisis; Ireland; Lisbon Treaty; referendum; sociotropic voting

\section{Issue}

This article is part of the issue 'The Politics, Promise and Peril of Direct Democracy', edited by Todd Donovan (Western Washington University, USA).

(C) 2019 by the authors; licensee Cogitatio (Lisbon, Portugal). This article is licensed under a Creative Commons Attribution 4.0 International License (CC BY).

\section{Introduction}

The use of plebiscites to decide matters of public policy in established democracies, even in states with a tradition of representative democracy, has been growing (Bjørklund, 2009; LeDuc, 2002b) to such an extent that 'one is tempted to say that we live in the age of referendums' (Qvortrup, 2018, p. 7). Their increased use has stimulated research into understanding what motivates voters to vote in a particular way in plebiscites. Multiple explanations have emerged. Second-order theories suggest their outcome in large part hinge on an incumbent government's popularity (Franklin, 2002;
Franklin, Marsh, \& Wleizen, 1994; van der Eijk, Franklin, \& Marsh, 1996). Other research highlights the importance of referendum campaigns (Darcy \& Laver, 1990; Pammett \& LeDuc, 2001; Quinlan, 2012), knowledge among voters of the plebiscite issue and where political elites stand on the issue (Elkink \& Sinnott, 2015; Hobolt, 2005, 2009) and voter attitudes on particular issues, for example, identity, or immigration, or in EU referendums sentiments regarding European integration (Clarke, Goodwin, \& Whiteley, 2017; Garry, Marsh, \& Sinnott, 2005; Hooghe \& Marks, 2004; McLaren, 2002; Svensson, 2002). Another school of thought focuses on utilitarian benefits or costs expected to accrue from vot- 
ing in a particular way in a referendum (Clarke et al., 2017; Gabel, 1998a, 1998b; Hobolt \& de Vries, 2016; Nadeau, Martin, \& Blais, 1999). Our contribution fits into this tradition as we dissect the impact of different economic motivations on vote choice in two Irish EU referendums on the same issue with the same government in situ but held in two dramatically different contexts.

Our interest lies in disentangling the different economic motivations, namely sociotropic versus egocentric utility. Our starting point is the extensive literature that has developed in the past two decades highlighting 'winners' from 'losers' of globalization (Gabel, 1998b; Gabel \& Whitten, 1997; Kriesi et al., 2008; Teney, Lacewell, $\&$ De Wilde, 2014). Cross-cutting traditional economic left-right and conservative-liberal dimensions of political division, 'winners' include middle-class left-wing voters with cosmopolitan values and liberal right-wing voters favouring international liberalization and free trade. Conversely, losers include working-class voters with both traditional left-wing values and those resorting to a stronger anti-immigration, more right-wing perspective (Teney et al., 2014). Studies of EU plebiscites and EU integration have investigated this research strand empirically by using both objective proxies for 'winner' and 'loser' status (Gabel, 1998a, 1998b; Rose \& Borz, 2016) and using subjective self-perception measures of an individual's personal economic situation (e.g., Clarke et al., 2017; Gabel $\&$ Whitten, 1997). While the evidence for utilitarian motivations shaping attitudes to European integration is plentiful, there is much less support for the utilitarian logic in shaping vote choice in elections. From the economic voting perspective, sociotropic motivations-an altruistic drive-are a significantly more potent driver of the voter vis-à-vis utilitarian motivations (Anderson, 2000; Kiewiet \& Lewis-Beck, 2011; Kinder \& Kiewiet, 1979; Lewis-Beck \& Stegmaier, 2013). Nonetheless, the impact of sociotropic motivations on support for European integration have been mixed (Eichenberg \& Dalton, 2007; Gomez, 2015; Hobolt \& de Vries, 2016). Hence, we are confronted with a puzzle that different economic motivations appear to be more important in shaping towards EU integration compared to the electoral arena. An EU integration referendum brings both these dimensions together and thus our interest lies in disentangling which is more important in driving the vote.

However, the role of context is also important. A plethora of literature has implied that the impact of economic motivations on the vote varies cross-nationally and depends on economic circumstances. Moreover, the Global Financial Crisis (GFC) brought economics to the forefront of the political agenda and research has shown that economics not only became more salient but also a significant predictor of vote choice in elections (Dassonneville \& Lewis-Beck, 2014; Singer, 2011; Talving, 2017). Its impact on referendum voting behaviour is much less known. Additionally, the GFC has sparked an increase in the literature on economic motivations and support for the European project (Bartkowska \&
Tiemann, 2015; Gomez, 2015; Hobolt \& de Vries, 2016). Yet, most of this research has not been from the perspective of the electoral arena. Literature exists implying that given this strength, variations in different motivations underlying economic voting-egocentric or sociotropic, utilitarian or altruistic-will be more starkly separable (Bartkowska \& Tiemann, 2015). In sum, our article's mission is to explore not only whether utilitarian or altruistic motives shape vote choice in referendums but also to explore whether differing economic contexts (pre- and post-GFC) shape voters' motivations in EU referendums.

Our study relies on data from two post-referendum surveys in Ireland on the Lisbon Treaty. Ireland offers an ideal testing ground for testing our assumptions regarding voting behaviour in EU plebiscites as it is a political imperative, if not a constitutional requirement, to hold a referendum on matters related to $\mathrm{EU}$ integration (Sinnott, 2005). As a result, Ireland has had more EU referendums than any other member state. The combination of two referendums in Ireland on the Lisbon Treaty either side of the onset of the GFC provides a unique opportunity to explore the impact of the economy in EU referendums where the same Treaty is being voted upon, in the same country, with the same government in situ, but crucially where the economic context between the two plebiscites is dramatically different. At the time of the first vote in June 2008, there appeared to be high confidence in Ireland's economic position with unemployment low, Ireland's fiscal position apparently sound, and voter confidence in the economy mostly positive. However, by the time of the second referendum in October 2009, the full impact of the GFC on Ireland was becoming apparent (Quinlan, 2012). A focus on EU referendums is also timely given their global implications beyond the state and, more recently, in light of Brexit.

We show that voters' economic motivations were different between 2008 and 2009. In 2008, voters were motivated by both utilitarian and sociotropic concerns, being more likely to have voted 'yes' when they felt their personal finances were good, when it was in their sociodemographic economic determined interests and if they felt the Treaty was good for Ireland's economy more generally. However, in 2009, the situation changed. While objective measures of the utilitarian model, such as social class and education, continued to impact voting behaviour, offering support to the theory, we find no evidence that subjective utilitarian measures mattered in 2009 after the onset of the GFC. Rather, voters focused on the national picture, with sociotropic concerns key, and voters substantially more likely to vote 'yes' in the expectation of an improvement in Ireland's economic prospects by doing so. Our results imply that sociotropic motivations are consistently important in shaping the vote in EU referendums despite the context, whereas the importance of utilitarian motives varies more so depending on the context.

Our article proceeds as follows: first, we outline our hypotheses within the literature on economic voting, mo- 
tivators of support for EU integration and voting in $\mathrm{EU}$ referendums. To put the analysis in context, we then provide a summary of the political and economic landscape in which the referendums took place, followed by our data and empirical analysis and discussion.

\section{Voters' Economic Motivations in Referendums}

\subsection{Economic Voting in Referendums: State of the Art}

'It's the economy, stupid!' the phrase coined by Bill Clinton's campaign team during his presidential run of 1992 captures the importance that economic assessments can have on voter behaviour. Numerous studies have confirmed its impact in various types of elections (Lewis-Beck, 1988; Lewis-Beck, Nadeau, \& Elias, 2008; Lewis-Beck \& Stegmaier, 2013; Okolikj \& Quinlan, 2016). In studies of referendums, economics has been found to be influential in high stakes plebiscites such as those dealing with constitutional change and succession in Canada and Scotland (Clarke, Kornberg, \& Stewart, 2004; Curtice, 2014; Nadeau et al., 1999). In EU referendums, voters' economic considerations were especially important in the swathe of accession referendums in the early 2000s (Doyle \& Fidirmuc, 2006; Tverdova \& Anderson, 2004) and in votes on specific EU treaties or issues (Aylott, 2005; Jupille \& Leblang, 2007) and more recently in accounting for vote choice in Britain's plebiscite on exiting the EU (Clarke et al., 2017). However, much of the existing research on EU referendums has been dominated by the 'second-order' (Franklin, 2002; Franklin et al., 1994) and 'issue-voting' models (Garry et al., 2005; Svensson, 2002), with the economy either gaining less attention, or when it has been the focus, being inter-linked with government popularity and thus subsumed under secondorder explanations. ${ }^{1}$ There is also cause to assume that the effect of the economy on support for EU integration increased more generally given the extent of economic control that has been delegated to the EU, especially for Eurozone countries. In sum, there is strong reason to assume that economics, be it at the macro or the individual level, will shape vote choice in EU referendums.

Two things are less clear, however. First, what economic motivations drive vote choice in EU plebiscites? On the one hand, the literature on European integration strongly highlights the role of utilitarian economic considerations, that is a focus on self-interest, in determining support for the EU (Eichenberg \& Dalton, 2007; Gabel, 1998a, 1998b; Gomez, 2015; Hobolt \& de Vries, 2016), thus implying that we might expect this to translate into egocentric motivations determining the vote. However, we are faced with a paradox. While the aforementioned literature shows a correlation between egocentric motivations and support for the EU, there has been much less empirical support found for egocentric voting in national elections (Kiewiet, 1983; Lewis-Beck, 1988; LewisBeck, Stubager, \& Nadeau, 2013), at least in comparison to the sociotropic model, where voters take a wider approach and focus on national level circumstances as opposed to personal ones. ${ }^{2}$ Hence, our contribution's first objective is to tease out the impacts of these different motivations on vote choice in EU referendums. Second, what is the role of context in conditioning the economic motivations of the voter in a referendum? A long tradition of research in the economic voting field has shown that context is crucial in determining how the economy shapes the vote from institutional configurations to the economic conditions voters are faced with (Anderson, 2000; Okolikj \& Quinlan, 2016; Powell \& Whitten, 1993). And while the GFC has spawned several studies of the economy's impact on vote and support for the EU, there has been scant exploration of how the economic conditions of the GFC influenced referendum voting (an exception is Clarke et al., 2017, and the Brexit referendum) or specifically how it conditioned voter economic motivations. Consequently, our second objective is to test whether economic voting calculus altered because of the GFC. Below, we develop our expectations.

\subsection{Egocentric and Sociotropic Economic Motivations in EU Referendums and the Role of Context}

As we mentioned above, the literature on economic voting has highlighted two different motivations: egocentric and sociotropic. To recapitulate the egocentric voting premise: it is a self-interested utilitarian response to the evaluation of the economy, where the voter looks primarily at his or her own economic situation (Melzer \& Richard, 1981; Nannestad \& Paldam, 1995, 1997). While the support for the hypothesis in the economic voting literature is minimal, in the context of support for EU integration the egocentric model has been especially successful in accounting for attitudes to the EU. The egocentric premise, at least regarding support for integration, can be looked at from two standpoints. The first is by exploring the objective socio-demographic characteristics of voters as proxy tests regarding their vulnerability to globalization. Advanced primarily by Gabel (1998a, 1998b), this approach posits that the economic advantages or disadvantages of EU integration will be different for particular social groups. For example, the benefits of the types of economic policies being advanced by the EU are more likely to be reaped by a young highly educated middle class professional who is in a better po-

\footnotetext{
${ }^{1}$ In addition to the second-order voting model, one might also expect party cues to play an important role in these referendums (cf. Hicks, Milner, \& Tingley, 2014). However, in the Irish case, a consensus on the EU has effectively existed between the main political parties, who were all broadly supportive of the notion of European integration. Consequently, Europe has not been a pivotal issue in Irish politics and receives little attention from the main parties outside EU referendums. This de facto 'elite withdrawal', whether by accident or design, has been pointed out by many scholars exploring Irish referendum voting behaviour (Darcy \& Laver, 1990; O’Mahony, 2009; Quinlan, 2012) and thus we would not expect partisan cues to be a strong feature in Irish referendums. We do investigate party cues as a robustness check in the Appendix in Table A2.

${ }^{2}$ Although for alternative evidence see Nannestad and Paldam (1997).
} 
sition to take advantage of market liberalization and the opportunities to travel, study abroad, etcetera, than by a middle-aged, low skilled labourer, who faces stronger employment competition from cheaper labour in new member states (Gabel, 1998a, 1998b; Gabel \& Palmer, 1995). Some scholars go so far as to argue that the onset of globalization has resulted in a new dimension of political contestation taking prominence in domestic politics of several states, with attitudes towards the EU, which by its very nature is a global institution committed to a free-market agenda, being a critical point of difference between political actors, cross-cutting traditional cleavages (Kriesi et al., 2008; Teney et al., 2014).

As the Lisbon referendums in Ireland were integrationist, we might assume that the expectations advanced by Gabel regarding general support for the EU translate into how certain groups behave at the ballot box. To test the Gabel egocentric model, we look at the sociodemographic groups that are most likely to be the 'losers' from globalization. Accordingly, we might expect citizens who are working-class, individuals towards the bottom of the income scale, older voters and less educated voters, both of whom are less likely to be beneficiaries of economic globalization, being less likely to support further integration efforts.

Consequently, we posit that:

Hypothesis 1a: Middle-class voters will have a greater likelihood of voting 'yes' compared with working-class voters in the Lisbon referendums.

Hypothesis $1 b$ : Highly educated voters will have a greater likelihood of voting 'yes' compared with less educated voters in the Lisbon referendums.

Hypothesis 1c: Younger voters will have a greater likelihood of voting 'yes' compared with older voters in the Lisbon referendums.

Testing utilitarian economic motivations does not end there. Our second means of doing so is the more conventional test of egocentric motivations, at least in the economic voting literature. This is where we explore how individuals perceive EU integration has influenced their personal financial situation. The idea is that voters who believe further integration or membership of the EU has been beneficial to them will be more amenable to further European integration. Consequently, in terms of referendum voting, we should see this translate into voting for the integrationist position. In our analysis, we take a retrospective evaluation of the personal economic situation as a proxy measure for this perception (see also Tucker, Pacek, \& Berinsky, 2002).

Hypothesis 2: Voters who are satisfied with their personal financial situation compared with voters who are dissatisfied will have a greater likelihood of voting 'yes' in the Lisbon referendums.
The most prominent economic evaluations in shaping vote choice have been sociotropic (e.g., Anderson, 2000; Lewis-Beck, 1988; Lewis-Beck \& Stegmaier, 2000, 2013). In this scenario, voters do not focus on personal circumstances but rather the economic benefits or losses that accrue to the national economy. In the context of an EU referendum, this would be economic benefits that accrue to the country as a consequence of EU integration. For example, voters may decide to vote 'yes' on the basis that support for the Treaty will result in more jobs coming to Ireland. In fact, one could argue that a panic factor is engendered by a crisis and that this results in individuals who had a severe anxiety about their economic situation becoming more likely to support integration. If this is the case, respondents who feel their personal economic situation is bad or segments of the population such as working-class voters are likely to support further integration in times of crisis, but it will also translate into a more general concern about the way the economy is managed and thus to sociotropic economic voting behaviour.

Hypothesis 3: Voters who believe Ireland's economic situation will improve as a consequence of further integration will have a greater likelihood of voting 'yes' in the Lisbon referendums.

All of our above suppositions have been focusing on the first research question concerning how we expect economic motivations to play out in referendum voting. However, our second question assumes context plays a role too. There is good cause to suspect that motivations could be conditional on the context voters face-both the direction and the magnitude of the effect. Between the two Lisbon referendums in Ireland, there was a substantial change in the economic conditions voters were faced with (see Section 3 for details). How might this play into referendum voting? Our supposition is that in an economic crisis, the economy takes on a greater saliency as information about the economy becomes more accessible to voters (Singer, 2011), the media gives greater coverage to the issue (Soroka, 2006), and voters tend to be particularly responsive to negative economic information (Dassonneville \& Lewis-Beck, 2014). Similarly, we might expect the referendum campaign in a time of economic crisis to be different to that of a campaign fought in a period of relative economic calm, with more focus on the national economy. As campaigns have been shown to be important in referendums in particular (LeDuc, 2002a), especially those where the partisan configuration is unconventional (LeDuc, 2015), we can expect this to significantly affect voter attitudes. Hence, with the onset of the GFC and the sense of 'panic' instilled on voters through this rhetoric, we expect sociotropic evaluations to be more prominent in determining the vote in 2009 than in times of prosperity, in the 2008 referendum. Hence, we assume that: 
Hypothesis 4: Sociotropic economic motivations compared with egocentric economic motivations will be stronger and thus have a greater impact on the likelihood of voting 'yes' in the 2009 Lisbon referendum.

\section{The Economic Context and the Two Lisbon Referendum Campaigns in Ireland}

As one of our contributions focuses on the impact of economic conditions on voters' economic motivations, some context regarding Ireland and the two referendums is warranted. The first referendum on the Lisbon Treaty in Ireland was held in June 2008 , where Irish voters rejected it by a margin of $53-47 \%$ (for more on the 2008 referendum, see Quinlan, 2009). While several factors contributed to this rejection (Sinnott, Elkink, O'Rourke, \& McBride,2009; Quinlan, 2009, for a summary) our interest is in the economic conditions voters were confronted with at the time of this first vote. At face value, the Irish economy appeared to be doing well: unemployment was at $6 \%$, below the EU average, economic growth for 2008 was still being forecast, and the nation's fiscal position appeared to be steady. Irish voters also seemed to be blissfully unaware of the economic tsunami that would hit the country later in 2008, with a Millward Brown/IMS opinion poll finding that $69 \%$ of Irish people described their economic situation as 'good' at the time of the 2008 vote (Quinlan, 2009). While the economy did feature as an issue in the first referendum campaign, the argument focused on the impact of the Treaty on Ireland's tax policy (Quinlan, 2009, p. 110). In sum, the 2008 referendum was held in an atmosphere where economic conditions, at least on the surface, appeared to be positive, and where the economy, particularly from a sociotropic perspective was not centre stage during the campaign.

However, the period between the first plebiscite and the second Lisbon referendum in October 2009 saw Ireland's economic landscape radically change, as the country endured its biggest economic downturn in its history. The GFC had serious implications for Ireland, due to the small and open nature of its economy. In autumn 2008 the Irish economy slid into recession for the first time since 1983 as the subprime mortgage crisis in the United States had global implications for banks and their ability to lend. This impact was further exacerbated because the Irish economy had become grossly over-reliant on the property and construction sectors during the economic boom years of the Celtic Tiger. Ireland's banks had engaged in large-scale property-related lending resulting in their balance sheets growing disproportionally large relative to the size of the economy. Consequently, Irish banks were hit particularly badly as the GFC took root. In September 2008, on the verge of insolvency, the government stepped in and guaranteed all Irish bank liabilities and recapitalised them using public funds. The Fianna Fail/Green government also controversially established the National Assets Management Agency, essentially a 'bad bank' which acquired property develop- ment loans from the banks in return for government debt bonds, all with the aim of restoring confidence to a banking system that seriously lacked credibility. All of this put a significant strain on Ireland's finances, already suffering from declining revenues with the collapse of the housing and construction booms. Between the two referendums, unemployment rose sharply, from 6 to 13\%, and Ireland's debt to GDP ratio increased substantially (Central Statistics Office, 2010a, 2010b). The government responded by introducing two austere budgets within 6 months, which saw sharp tax rises and substantial cuts in public expenditure. In the 17-month period between the first and second referendums, the country's economic decline was unprecedented as GDP fell by between 11 and $12 \%$ in the first three quarters of 2009 (Central Statistics Office, 2010a). Voter confidence in the economy also tanked (Sinnott \& Elkink, 2010), while government popularity plummeted, with the ruling coalition parties, Fianna Fail and the Green suffering an electoral shellacking in the June 2009 European and local government elections (Quinlan, 2010).

These changed economic circumstances saw the second referendum campaign dominated by the economy (for more detail on the second referendum, see Quinlan, 2012). Those advocating a 'yes' vote linked Ireland's future economic success to membership of the EU, making economic recovery and employment central planks of their campaign. The 'no' side countered that supporters of the Treaty were playing on peoples' economic anxieties and urged voters to use the referendum as an opportunity to punish the government for their handling of the economy. Consequently, the economy was far more central to the 2009 referendum than to the 2008 campaign.

While the economic conditions represented the most seismic changes between the two referendums, two other conditions merit mention. The first was the procurement by the Irish government of legal guarantees in June 2009 stating the Lisbon Treaty in no way affected Irish tax policy or the country's neutrality, and abortion policy, with concern over these issues in the first vote having increased the likelihood of people voting 'no' (Sinnott et al., 2009). Hence, these guarantees reduced the saliency of these issues in the second referendum. Second, the campaigns waged by protagonists on both sides changed considerably. While the 'yes' campaign in the first referendum was of poor quality (Quinlan, 2012, p. 143), in 2009 it was the more active and cohesive of the two campaigns. It received the support of the influential Irish Farming Association (IFA) early on in the campaign, (whereas in 2008 the IFA had been a late convert to the 'yes' side), and the country's largest trade union, Services, Industrial, Professional and Technical Union, which had remained neutral in 2008. Meanwhile, the 'no' side's main protagonist in the 2008 plebiscite, Libertas, had lost much of its political impetus by 2009 after its defeat in the 2009 European elections (Quinlan, 2012, p. 145). 
In sum, while it is evident that the legal guarantees and the campaigns represent two additional changed conditions between Lisbon I and Lisbon II, the primary contextual difference between 2008 and 2009 was that voters faced dramatically different economic conditions. Indeed, it could be argued that the more intense campaigning on the part of the 'yes' side, including the support of the unions and the farmers, was driven by these circumstances. We posit that the shift in economic conditions were the starkest and most important change. Moreover, despite the legal guarantees provided to the Irish government, we should not lose sight that voters voted upon the exact same Treaty in both plebiscites with not one word of the Lisbon Treaty altered because of the first rejection.

\section{Research Strategy}

\subsection{Data}

Our data comes from two post-referendum surveys: the first fielded between 24 and 31 July 2008, two weeks after the June 2008 vote, and the second between 20 and 23 November 2009, six weeks after the October 2009 plebiscite. These data were commissioned by the Irish Department of Foreign Affairs, in collaboration with an independent polling company, Millward Brown Lansdowne. The face-to-face surveys had sample sizes of 2,101 and 1,002 respondents, respectively, and were designed to be representative of all persons eligible to vote. Quotas were set according to the 2006 Irish census based on region, sex, age, and socio-economic group.

\subsection{Modelling Strategy and Variable Operationalization}

It is common in the analysis of referendums to investigate the decision to vote or abstain and whether the individual voted 'yes' or 'no' separately. While we perform these tests for robustness, our analysis is based on an integration of these two steps in one logistic model. We employ this strategy because of the inherent interdependence between the two behaviours. The decision whether or not to vote can be expected to be influenced by how strongly a voter feels about the referendum issue, such that the utility attached to a 'yes' or 'no' outcome not only influences vote choice, but also turnout. Our model follows that of Sattler and Urpelainen (2012), which is the referendum equivalent to the two-candidate election model developed in Sanders (1998). In these models, a latent utility of a 'yes' vote is interpreted in a number of different, compatible ways: a) a positive value indicates a propensity to vote 'yes'; b) a negative value indicates a propensity to vote 'no'; $c$ ) the absolute value indicates how strongly one feels about this preference; and d) the stronger one's preference, the more likely one is to vote despite the cost of doing so. ${ }^{3}$ This model implies that voters consider the utilities of a 'yes' or 'no' prior to their decision whether or not to participate in the referendum: those with a strong opinion regarding the referendum outcome will be more likely to vote. Some explanations of turnout, such as those referring to a sense of duty to vote or levels of apathy towards the political system, precede the vote choice decision such that those who do not feel compelled to vote will also not evaluate the relative utilities of either vote outcome. Our modelling approach assumes that these factors capture the cost component of the model.

Turning to the survey questions and operationalizations of our variables, our sociotropic measure is based on a question that looks at people's expectations regarding Ireland's economic prospects given a 'yes' vote. Respondents were asked in 2008: 'Do you think that, as a result of the 'NO' vote in the Lisbon Treaty referendum, Ireland's economic prospects have been improved or disimproved or remain unchanged?', and in 2009: 'Do you think that, as a result of the 'YES' vote in the Lisbon Treaty referendum, Ireland's economic prospects have been improved or disimproved or remain unchanged?' This diverges somewhat from the traditional sociotropic economy question as the formulation of the question assumes a more conscious linkage in the respondent's mind between the vote and the economic consequences of the Treaty, which might result in the sociotropic effect being underestimated, as it is conceivable that citizens might unconsciously vote based on general expectations not implicitly tied up with the Treaty. Given the finding by Dassonneville and Lewis-Beck (2014) that a negative change in the economy has a much stronger effect on sociotropic voting than a positive change in the economy, we separately include a dummy variable for expecting improved economic prospects due to a 'yes' vote and one for expecting worsened economic prospects.

We tap utilitarian economic voting in two different ways. The first is the conventional egocentric measure which asks respondents to evaluate their personal economic situation. We capture this through respondents' answer to the following question: 'What about your own economic situation these days? Would you say it is very good, fairly good, fairly bad or very bad?' Again, this question slightly deviates from the traditional measure which is more explicitly retrospective or prospective and usually imposes a time limit. Hence, the asymmetry between the sociotropic and egocentric measure and the Treaty being voted upon needs to be considered a caveat to our findings. Moreover, we recognize that some question whether voter perceptions of economic circumstances, be they egocentric or sociotropic, are heavily contaminated by partisan bias (Evans \& Anderson, 2006; Wlezien, Franklin, \& Twiggs, 1997). However, persuasive evidence exists showing economics has a direct effect on vote, and if anything, cross-sectional analysis may suppress the true impact of economic voting (Fraile \& LewisBeck, 2014; Lewis-Beck et al., 2008). In any event, our second measures, in the vein of Gabel (1998a, 1998b),

\footnotetext{
${ }^{3}$ See Sattler and Urpelainen (2012) for the technical details and the resulting log-likelihood function.
} 
circumvent the endogeneity critique and capture the behaviour of various socio-demographic groups (class, education, and age) to assess if utilitarian motivations are being channelled through an individual's socio-economic circumstances. While our focus is on the economy, we include covariates reflecting several alternative theoretical explanations of vote choice in EU referendums. ${ }^{4}$

\section{Results}

Table 1 presents the results for Hypotheses $1 \mathrm{a}-\mathrm{c}$ based on demographic variables where attitudinal variables would be inappropriate controls. Based on these mea- sures it is clear that the utilitarian argument regarding different groups favouring EU integration holds across both Lisbon referendums. Working class voters are significantly less likely to vote 'yes' than middle class voters (H1a)-although the classification between 'unskilled' and 'skilled' does not appear to make much difference. Those with higher levels of education are more likely to vote 'yes' (H 1b)..$^{5}$ These effects persist with similar magnitude across the two referendums, despite the onset of the GFC. However, the effect on the different age groups is contrary to that expected by the 'winners' and 'losers' hypothesis (H 1c). Instead, older voters were more likely to vote 'yes' than younger voters.

Table 1. Logistic random utility regressions (Sattler \& Urpelainen, 2012) explaining vote choice in the 2008 and 2009 Lisbon referendums in Ireland, based on demographic variables.

\begin{tabular}{|c|c|c|c|c|c|c|c|c|}
\hline & \multicolumn{4}{|c|}{2008} & \multicolumn{4}{|c|}{2009} \\
\hline & \multicolumn{2}{|c|}{ Model 1} & \multicolumn{2}{|c|}{ Model 2} & \multicolumn{2}{|c|}{ Model 3} & \multicolumn{2}{|c|}{ Model 4} \\
\hline & Cost & Utility & Cost & Utility & Cost & Utility & Cost & Utility \\
\hline Female & & $\begin{array}{c}-0.12 \\
(0.08)\end{array}$ & & $\begin{array}{c}-0.12 \\
(0.08)\end{array}$ & & $\begin{array}{c}-0.17 \\
(0.12)\end{array}$ & & $\begin{array}{r}-0.16 \\
(0.12)\end{array}$ \\
\hline Age 18-24 & $\begin{array}{l}1.06 * * \\
(0.13)\end{array}$ & $\begin{array}{c}-0.22 \\
(0.17)\end{array}$ & $\begin{array}{l}1.22^{* *} \\
(0.14)\end{array}$ & $\begin{array}{c}-0.38^{* *} \\
(0.18)\end{array}$ & $\begin{array}{c}0.95^{* *} \\
(0.22)\end{array}$ & $\begin{array}{c}-0.43^{*} \\
(0.25)\end{array}$ & $\begin{array}{l}1.10^{* *} \\
(0.23)\end{array}$ & $\begin{array}{c}-0.65^{* *} \\
(0.26)\end{array}$ \\
\hline Age 25-34 & $\begin{array}{l}0.88^{* *} \\
(0.13)\end{array}$ & $\begin{array}{c}-0.35^{* *} \\
(0.15)\end{array}$ & $\begin{array}{l}0.99 * * \\
(0.14)\end{array}$ & $\begin{array}{c}-0.46^{* *} \\
(0.16)\end{array}$ & $\begin{array}{c}0.41^{*} \\
(0.22)\end{array}$ & $\begin{array}{c}-0.36 \\
(0.22)\end{array}$ & $\begin{array}{l}0.52 * * \\
(0.23)\end{array}$ & $\begin{array}{c}-0.51^{* *} \\
(0.23)\end{array}$ \\
\hline Age 35-49 & $\begin{array}{l}0.45^{* *} \\
(0.13)\end{array}$ & $\begin{array}{c}-0.16 \\
(0.14)\end{array}$ & $\begin{array}{l}0.52^{* *} \\
(0.14)\end{array}$ & $\begin{array}{c}-0.24 \\
(0.15)\end{array}$ & $\begin{array}{c}-0.06 \\
(0.23)\end{array}$ & $\begin{array}{c}-0.42 * * \\
(0.21)\end{array}$ & $\begin{array}{c}0.03 \\
(0.23)\end{array}$ & $\begin{array}{c}-0.54^{* *} \\
(0.22)\end{array}$ \\
\hline Age 50-64 & $\begin{array}{c}0.13 \\
(0.14)\end{array}$ & $\begin{array}{c}-0.16 \\
(0.14)\end{array}$ & $\begin{array}{c}0.17 \\
(0.15)\end{array}$ & $\begin{array}{c}-0.20 \\
(0.15)\end{array}$ & $\begin{array}{c}-0.30 \\
(0.25)\end{array}$ & $\begin{array}{c}-0.18 \\
(0.22)\end{array}$ & $\begin{array}{c}-0.25 \\
(0.25)\end{array}$ & $\begin{array}{c}-0.25 \\
(0.23)\end{array}$ \\
\hline Lower middle class & $\begin{array}{c}0.15 \\
(0.12)\end{array}$ & $\begin{array}{c}-0.33^{* *} \\
(0.14)\end{array}$ & $\begin{array}{c}0.09 \\
(0.12)\end{array}$ & $\begin{array}{c}-0.27^{* *} \\
(0.14)\end{array}$ & $\begin{array}{c}-0.25 \\
(0.22)\end{array}$ & $\begin{array}{c}-0.49 * * \\
(0.22)\end{array}$ & $\begin{array}{c}-0.27 \\
(0.22)\end{array}$ & $\begin{array}{c}-0.44^{*} \\
(0.22)\end{array}$ \\
\hline Skilled working class & $\begin{array}{l}0.33^{* *} \\
(0.12)\end{array}$ & $\begin{array}{c}-0.81^{* *} \\
(0.14)\end{array}$ & $\begin{array}{c}0.17 \\
(0.13)\end{array}$ & $\begin{array}{c}-0.65^{* *} \\
(0.15)\end{array}$ & $\begin{array}{c}0.08 \\
(0.22)\end{array}$ & $\begin{array}{c}-0.99 * * \\
(0.23)\end{array}$ & $\begin{array}{c}-0.04 \\
(0.23)\end{array}$ & $\begin{array}{c}-0.78^{* *} \\
(0.24)\end{array}$ \\
\hline Unskilled working class & $\begin{array}{l}0.55^{* *} \\
(0.12)\end{array}$ & $\begin{array}{c}-0.86^{* *} \\
(0.15)\end{array}$ & $\begin{array}{l}0.38^{* *} \\
(0.13)\end{array}$ & $\begin{array}{c}-0.70 * * \\
(0.16)\end{array}$ & $\begin{array}{c}0.11 \\
(0.22)\end{array}$ & $\begin{array}{c}-0.99 * * \\
(0.22)\end{array}$ & $\begin{array}{c}-0.05 \\
(0.23)\end{array}$ & $\begin{array}{c}-0.76^{* *} \\
(0.24)\end{array}$ \\
\hline Farmer & $\begin{array}{c}-0.02 \\
(0.18)\end{array}$ & $\begin{array}{c}0.23 \\
(0.19)\end{array}$ & $\begin{array}{c}-0.16 \\
(0.18)\end{array}$ & $\begin{array}{c}-0.07 \\
(0.20)\end{array}$ & $\begin{array}{c}-0.34 \\
(0.36)\end{array}$ & $\begin{array}{c}-0.29 \\
(0.33)\end{array}$ & $\begin{array}{c}-0.46 \\
(0.37)\end{array}$ & $\begin{array}{c}-0.11 \\
(0.34)\end{array}$ \\
\hline Secondary education & & & $\begin{array}{c}-0.08 \\
(0.14)\end{array}$ & $\begin{array}{c}0.09 \\
(0.17)\end{array}$ & & & $\begin{array}{c}-0.22 \\
(0.22)\end{array}$ & $\begin{array}{c}0.17 \\
(0.25)\end{array}$ \\
\hline Third level education & & & $\begin{array}{c}-0.38^{* *} \\
(0.15)\end{array}$ & $\begin{array}{c}0.35^{*} \\
(0.19)\end{array}$ & & & $\begin{array}{c}-0.46^{*} \\
(0.26)\end{array}$ & $\begin{array}{c}0.57^{* *} \\
(0.28)\end{array}$ \\
\hline Intercept & $\begin{array}{c}-1.06^{* *} \\
(0.15)\end{array}$ & $\begin{array}{l}0.50 * * \\
(0.16)\end{array}$ & $\begin{array}{c}-0.84^{* *} \\
(0.18)\end{array}$ & $\begin{array}{c}0.28 \\
(0.21)\end{array}$ & $\begin{array}{c}-0.79 * * \\
(0.26)\end{array}$ & $\begin{array}{l}1.53^{* *} \\
(0.26)\end{array}$ & $\begin{array}{c}-0.51^{*} \\
(0.31)\end{array}$ & $\begin{array}{c}1.20 * * \\
(0.33)\end{array}$ \\
\hline$N$ & & & & & & & & \\
\hline$A I C$ & 43 & & 43 & & & & & \\
\hline
\end{tabular}

Notes: ${ }^{*} p \leq 0.10 ; * * p \leq 0.05$. Standard errors in parentheses. Because of high collinearity between age, class, and education, models are estimated with and without education included. Cost is modelled with a dummy for abstention as dependent variable; utility with a dummy variable for a 'yes' vote as dependent variable.

\footnotetext{
${ }^{4}$ Full details of the operationalizations of our variables and summary statistics are detailed in the Appendix.

${ }^{5}$ Due to high multicollinearity when age, class, and education are all three included, we present separate models with and without the education variable. For Model 2, the highest Variance Inflation Factor (VIF) is 4.65, while for Model 1 this is reduced to 2.27; for Model 4 the highest VIF is 5.01, reduced to 2.26 in Model 3. Typically used threshold values for multicollinearity are VIF scores of 4, 6, or 10, and therefore there is no real concern with high multicollinearity in our models (O'Brien, 2007). For the more extensive specification, models 5-8, education is always included, since the demographics are mere control variables and therefore high multicollinearity among them is not a concern. The highest observed VIF score across all models is 5.25 , for education.
} 
Table 2 provides the tests of Hypotheses 2 and 3. Here demographic variables are included as controls, alongside other covariates related to government satisfaction and political knowledge, and attitudes towards identity and immigration. We present models with and without attitudinal control variables. In models 5 and 6 , which relate to the 2008 referendum and before the GFC took root, we see an effect in line with $\mathrm{H} 2$. We observe that a negative evaluation of the voter's personal economic situation led voters to be more likely to reject the Treaty. However, for 2009 (i.e., post the shock of the
GFC), this variable, presented in models 7 and 8 , has a statistically insignificant, positive effect. This is an important shift-voters' personal economic security shaped vote choice in 2008 when the economic climate was more positive, whereas in 2009, these egocentric considerations were much less relevant when the crisis was apparent. It supports the proposition that context conditions the economic vote and we can deduce support that the GFC resulted in a shift in economic calculus among voters.

In line with $\mathrm{H} 3$, voters were strongly inclined to vote 'yes' by sociotropic utility-i.e., by the perception that

Table 2. Logistic random utility regressions (Sattler \& Urpelainen, 2012) explaining vote choice in the 2008 and 2009 Lisbon referendums in Ireland.

\begin{tabular}{|c|c|c|c|c|c|c|c|c|}
\hline & \multicolumn{4}{|c|}{2008} & \multicolumn{4}{|c|}{2009} \\
\hline & \multicolumn{2}{|c|}{ Model 5} & \multicolumn{2}{|c|}{ Model 6} & \multicolumn{2}{|c|}{ Model 7} & \multicolumn{2}{|c|}{ Model 8} \\
\hline & Cost & Utility & Cost & Utility & Cost & Utility & Cost & Utility \\
\hline Female & & $\begin{array}{c}-0.06 \\
(0.10)\end{array}$ & & $\begin{array}{c}-0.04 \\
(0.10)\end{array}$ & & $\begin{array}{c}-0.09 \\
(0.15)\end{array}$ & & $\begin{array}{r}-0.19 \\
(0.17)\end{array}$ \\
\hline Age 18-24 & $\begin{array}{l}0.97 * * \\
(0.15)\end{array}$ & $\begin{array}{c}-0.39 * \\
(0.22)\end{array}$ & $\begin{array}{l}0.93 * * \\
(0.16)\end{array}$ & $\begin{array}{c}-0.35 \\
(0.23)\end{array}$ & $\begin{array}{l}0.66 * * \\
(0.25)\end{array}$ & $\begin{array}{c}-0.41 \\
(0.32)\end{array}$ & $\begin{array}{l}0.55^{* *} \\
(0.28)\end{array}$ & $\begin{array}{c}-0.71^{*} \\
(0.37)\end{array}$ \\
\hline Age 25-34 & $\begin{array}{l}0.96^{* *} \\
(0.14)\end{array}$ & $\begin{array}{c}-0.63 * * \\
(0.18)\end{array}$ & $\begin{array}{c}0.90^{* *} \\
(0.15)\end{array}$ & $\begin{array}{c}-0.60 * * \\
(0.19)\end{array}$ & $\begin{array}{c}0.35 \\
(0.24)\end{array}$ & $\begin{array}{c}-0.50^{*} \\
(0.28)\end{array}$ & $\begin{array}{c}0.28 \\
(0.27)\end{array}$ & $\begin{array}{c}-0.40 \\
(0.32)\end{array}$ \\
\hline Age 35-49 & $\begin{array}{l}0.54^{* *} \\
(0.14)\end{array}$ & $\begin{array}{c}-0.29 * \\
(0.17)\end{array}$ & $\begin{array}{l}0.53^{* *} \\
(0.15)\end{array}$ & $\begin{array}{c}-0.26 \\
(0.18)\end{array}$ & $\begin{array}{c}0.09 \\
(0.24)\end{array}$ & $\begin{array}{c}-0.34 \\
(0.26)\end{array}$ & $\begin{array}{c}0.01 \\
(0.27)\end{array}$ & $\begin{array}{c}-0.38 \\
(0.30)\end{array}$ \\
\hline Age 50-64 & $\begin{array}{c}0.19 \\
(0.15)\end{array}$ & $\begin{array}{c}-0.23 \\
(0.17)\end{array}$ & $\begin{array}{c}0.22 \\
(0.16)\end{array}$ & $\begin{array}{c}-0.17 \\
(0.18)\end{array}$ & $\begin{array}{c}-0.06 \\
(0.26)\end{array}$ & $\begin{array}{c}-0.30 \\
(0.27)\end{array}$ & $\begin{array}{c}-0.17 \\
(0.29)\end{array}$ & $\begin{array}{c}-0.44 \\
(0.32)\end{array}$ \\
\hline Lower middle class & $\begin{array}{c}-0.13 \\
(0.12)\end{array}$ & $\begin{array}{c}-0.10 \\
(0.16)\end{array}$ & $\begin{array}{r}-0.08 \\
(0.12)\end{array}$ & $\begin{array}{r}-0.07 \\
(0.16)\end{array}$ & $\begin{array}{c}-0.46^{*} \\
(0.24)\end{array}$ & $\begin{array}{c}-0.20 \\
(0.27)\end{array}$ & $\begin{array}{c}-0.47^{*} \\
(0.26)\end{array}$ & $\begin{array}{r}-0.09 \\
(0.30)\end{array}$ \\
\hline Skilled working class & $\begin{array}{c}-0.16 \\
(0.13)\end{array}$ & $\begin{array}{c}-0.41 * * \\
(0.18)\end{array}$ & $\begin{array}{c}-0.14 \\
(0.13)\end{array}$ & $\begin{array}{c}-0.33^{*} \\
(0.19)\end{array}$ & $\begin{array}{c}-0.23 \\
(0.24)\end{array}$ & $\begin{array}{c}-0.44 \\
(0.29)\end{array}$ & $\begin{array}{c}0.23 \\
(0.27)\end{array}$ & $\begin{array}{c}-0.39 \\
(0.33)\end{array}$ \\
\hline Unskilled working class & $\begin{array}{c}-0.03 \\
(0.13)\end{array}$ & $\begin{array}{c}-0.37^{*} \\
(0.19)\end{array}$ & $\begin{array}{c}-0.02 \\
(0.14)\end{array}$ & $\begin{array}{c}-0.28 \\
(0.20)\end{array}$ & $\begin{array}{c}-0.36 \\
(0.25)\end{array}$ & $\begin{array}{c}-0.21 \\
(0.30)\end{array}$ & $\begin{array}{c}-0.39 \\
(0.27)\end{array}$ & $\begin{array}{c}-0.17 \\
(0.33)\end{array}$ \\
\hline Farmer & $\begin{array}{c}-0.32 * \\
(0.19)\end{array}$ & $\begin{array}{c}-0.05 \\
(0.24)\end{array}$ & $\begin{array}{c}-0.24 \\
(0.19)\end{array}$ & $\begin{array}{c}0.07 \\
(0.24)\end{array}$ & $\begin{array}{c}-0.45 \\
(0.37)\end{array}$ & $\begin{array}{c}-0.07 \\
(0.42)\end{array}$ & $\begin{array}{c}-0.96^{*} \\
(0.52)\end{array}$ & $\begin{array}{c}0.41 \\
(0.49)\end{array}$ \\
\hline Secondary education & $\begin{array}{c}0.09 \\
(0.14)\end{array}$ & $\begin{array}{c}0.03 \\
(0.21)\end{array}$ & $\begin{array}{c}0.16 \\
(0.15)\end{array}$ & $\begin{array}{c}-0.06 \\
(0.22)\end{array}$ & $\begin{array}{c}-0.21 \\
(0.24)\end{array}$ & $\begin{array}{c}0.02 \\
(0.31)\end{array}$ & $\begin{array}{c}-0.15 \\
(0.28)\end{array}$ & $\begin{array}{r}-0.08 \\
(0.36)\end{array}$ \\
\hline Third level education & $\begin{array}{c}0.05 \\
(0.16)\end{array}$ & $\begin{array}{c}0.10 \\
(0.24)\end{array}$ & $\begin{array}{c}0.13 \\
(0.16)\end{array}$ & $\begin{array}{c}-0.03 \\
(0.25)\end{array}$ & $\begin{array}{c}-0.25 \\
(0.28)\end{array}$ & $\begin{array}{c}0.38 \\
(0.35)\end{array}$ & $\begin{array}{c}-0.11 \\
(0.32)\end{array}$ & $\begin{array}{c}-0.01 \\
(0.40)\end{array}$ \\
\hline Objective knowl. EU & $\begin{array}{c}-0.35^{* *} \\
(0.08)\end{array}$ & $\begin{array}{l}0.31 * * \\
(0.12)\end{array}$ & $\begin{array}{c}-0.29 * * \\
(0.08)\end{array}$ & $\begin{array}{c}0.19 \\
(0.12)\end{array}$ & $\begin{array}{c}-0.08 \\
(0.14)\end{array}$ & $\begin{array}{c}0.32 * \\
(0.17)\end{array}$ & $\begin{array}{c}0.10 \\
(0.15)\end{array}$ & $\begin{array}{c}0.10 \\
(0.19)\end{array}$ \\
\hline Subjective knowl. EU & $\begin{array}{c}-0.18^{*} \\
(0.09)\end{array}$ & $\begin{array}{c}0.02 \\
(0.13)\end{array}$ & $\begin{array}{c}-0.15^{*} \\
(0.09)\end{array}$ & $\begin{array}{c}-0.06 \\
(0.14)\end{array}$ & $\begin{array}{c}-0.31^{*} \\
(0.19)\end{array}$ & $\begin{array}{c}0.41 * \\
(0.21)\end{array}$ & $\begin{array}{c}-0.16 \\
(0.21)\end{array}$ & $\begin{array}{c}0.26 \\
(0.24)\end{array}$ \\
\hline Subjective knowl. Treaty & $\begin{array}{c}-1.14^{* *} \\
(0.10)\end{array}$ & $\begin{array}{l}0.46^{* *} \\
(0.13)\end{array}$ & $\begin{array}{c}-1.12^{* *} \\
(0.10)\end{array}$ & $\begin{array}{l}0.51^{* *} \\
(0.13)\end{array}$ & $\begin{array}{c}-0.98^{* *} \\
(0.18)\end{array}$ & $\begin{array}{c}-0.30 \\
(0.21)\end{array}$ & $\begin{array}{c}-1.15^{* *} \\
(0.20)\end{array}$ & $\begin{array}{c}-0.31 \\
(0.24)\end{array}$ \\
\hline Own econ. situation bad & & $\begin{array}{c}-0.38^{* *} \\
(0.12)\end{array}$ & & $\begin{array}{c}-0.31^{* *} \\
(0.12)\end{array}$ & & $\begin{array}{c}0.09 \\
(0.16)\end{array}$ & & $\begin{array}{c}0.16 \\
(0.18)\end{array}$ \\
\hline Econ. prosp. improved & & $\begin{array}{c}-0.44^{* *} \\
(0.20)\end{array}$ & & $\begin{array}{c}-0.47^{* *} \\
(0.21)\end{array}$ & & $\begin{array}{c}1.82^{* *} \\
(0.18)\end{array}$ & & $\begin{array}{c}1.53^{* *} \\
(0.20)\end{array}$ \\
\hline Econ. prosp. disimproved & & $\begin{array}{l}0.75^{* *} \\
(0.11)\end{array}$ & & $\begin{array}{l}0.73^{* *} \\
(0.11)\end{array}$ & & $\begin{array}{c}-0.94^{* *} \\
(0.26)\end{array}$ & & $\begin{array}{c}-0.41 \\
(0.30)\end{array}$ \\
\hline Dissatisfaction government & $\begin{array}{l}0.20 * * \\
(0.07)\end{array}$ & $\begin{array}{c}-0.65^{* *} \\
(0.11)\end{array}$ & $\begin{array}{c}0.16 * * \\
(0.07)\end{array}$ & $\begin{array}{c}-0.55^{* *} \\
(0.11)\end{array}$ & $\begin{array}{c}-0.26 \\
(0.19)\end{array}$ & $\begin{array}{c}-0.47^{*} \\
(0.25)\end{array}$ & $\begin{array}{c}-0.13 \\
(0.21)\end{array}$ & $\begin{array}{c}-0.36 \\
(0.27)\end{array}$ \\
\hline
\end{tabular}


Table 2. (Cont.) Logistic random utility regressions (Sattler \& Urpelainen, 2012) explaining vote choice in the 2008 and 2009 Lisbon referendums in Ireland.

\begin{tabular}{|c|c|c|c|c|c|c|c|c|}
\hline & \multicolumn{4}{|c|}{2008} & \multicolumn{4}{|c|}{2009} \\
\hline & \multicolumn{2}{|c|}{ Model 5} & \multicolumn{2}{|c|}{ Model 6} & \multicolumn{2}{|c|}{ Model 7} & \multicolumn{2}{|c|}{ Model 8} \\
\hline & Cost & Utility & Cost & Utility & Cost & Utility & Cost & Utility \\
\hline Fine Gael & $\begin{array}{c}0.08 \\
(0.12)\end{array}$ & $\begin{array}{c}-0.28 * \\
(0.15)\end{array}$ & $\begin{array}{c}0.06 \\
(0.12)\end{array}$ & $\begin{array}{c}-0.30^{*} \\
(0.16)\end{array}$ & $\begin{array}{c}-0.02 \\
(0.23)\end{array}$ & $\begin{array}{c}-0.34 \\
(0.25)\end{array}$ & $\begin{array}{c}-0.15 \\
(0.26)\end{array}$ & $\begin{array}{c}-0.25 \\
(0.28)\end{array}$ \\
\hline Sinn Fein & $\begin{array}{c}0.26 \\
(0.17)\end{array}$ & $\begin{array}{c}-1.08^{* *} \\
(0.29)\end{array}$ & $\begin{array}{c}0.27 \\
(0.17)\end{array}$ & $\begin{array}{c}-0.92 * * \\
(0.31)\end{array}$ & $\begin{array}{c}0.25 \\
(0.31)\end{array}$ & $\begin{array}{c}-0.96 * * \\
(0.36)\end{array}$ & $\begin{array}{c}-0.01 \\
(0.34)\end{array}$ & $\begin{array}{c}-0.85^{* *} \\
(0.40)\end{array}$ \\
\hline Labour & $\begin{array}{c}-0.01 \\
(0.15)\end{array}$ & $\begin{array}{c}-0.35^{*} \\
(0.20)\end{array}$ & $\begin{array}{c}0.07 \\
(0.14)\end{array}$ & $\begin{array}{c}-0.44 * * \\
(0.21)\end{array}$ & $\begin{array}{c}-0.13 \\
(0.25)\end{array}$ & $\begin{array}{c}-0.84^{* *} \\
(0.25)\end{array}$ & $\begin{array}{c}-0.28 \\
(0.27)\end{array}$ & $\begin{array}{c}-0.64^{* *} \\
(0.29)\end{array}$ \\
\hline Green Party & $\begin{array}{c}0.03 \\
(0.23)\end{array}$ & $\begin{array}{c}-0.52^{*} \\
(0.28)\end{array}$ & $\begin{array}{l}-0.07 \\
(0.23)\end{array}$ & $\begin{array}{c}-0.45 \\
(0.28)\end{array}$ & $\begin{array}{c}0.73 * * \\
(0.31)\end{array}$ & $\begin{array}{c}-1.00 \\
(0.43)\end{array}$ & $\begin{array}{c}0.73 * * \\
(0.33)\end{array}$ & $\begin{array}{c}-0.88^{*} \\
(0.48)\end{array}$ \\
\hline Other & $\begin{array}{c}-0.19 \\
(0.24)\end{array}$ & $\begin{array}{c}-0.86^{* *} \\
(0.28)\end{array}$ & $\begin{array}{c}-0.14 \\
(0.23)\end{array}$ & $\begin{array}{c}-0.86 * * \\
(0.30)\end{array}$ & $\begin{array}{c}0.14 \\
(0.34)\end{array}$ & $\begin{array}{c}-0.61 \\
(0.43)\end{array}$ & $\begin{array}{c}-0.36 \\
(0.42)\end{array}$ & $\begin{array}{c}-0.63 \\
(0.50)\end{array}$ \\
\hline No party & $\begin{array}{l}0.29 * * \\
(0.09)\end{array}$ & $\begin{array}{c}-0.72 * * \\
(0.13)\end{array}$ & $\begin{array}{l}0.25 * * \\
(0.09)\end{array}$ & $\begin{array}{c}-0.77^{* *} \\
(0.13)\end{array}$ & $\begin{array}{c}0.29 \\
(0.18)\end{array}$ & $\begin{array}{c}-0.70 * * \\
(0.21)\end{array}$ & $\begin{array}{c}0.20 \\
(0.20)\end{array}$ & $\begin{array}{c}-0.57^{* *} \\
(0.24)\end{array}$ \\
\hline Irish identity & $\begin{array}{c}0.10 \\
(0.07)\end{array}$ & $\begin{array}{c}-0.45^{* *} \\
(0.11)\end{array}$ & $\begin{array}{c}0.07 \\
(0.07)\end{array}$ & $\begin{array}{c}-0.26 * * \\
(0.11)\end{array}$ & $\begin{array}{c}-0.03 \\
(0.13)\end{array}$ & $\begin{array}{c}-0.63^{* *} \\
(0.16)\end{array}$ & $\begin{array}{c}-0.18 \\
(0.15)\end{array}$ & $\begin{array}{c}-0.49 * * \\
(0.18)\end{array}$ \\
\hline Anti-immigration & & & & $\begin{array}{c}-0.39 * * \\
(0.11)\end{array}$ & & & & $\begin{array}{c}0.20 \\
(0.18)\end{array}$ \\
\hline EU memb. is a good thing & & & $\begin{array}{c}-0.31^{* *} \\
(0.08)\end{array}$ & $\begin{array}{l}0.69 * * \\
(0.15)\end{array}$ & & & $\begin{array}{c}-0.37^{* *} \\
(0.16)\end{array}$ & $\begin{array}{c}1.85^{* *} \\
(0.22)\end{array}$ \\
\hline Pro-neutrality attitude & & & $\begin{array}{c}0.09 \\
(0.07)\end{array}$ & $\begin{array}{c}-0.63^{* *} \\
(0.10)\end{array}$ & & & $\begin{array}{c}-0.24^{*} \\
(0.14)\end{array}$ & $\begin{array}{c}-0.79 * * \\
(0.18)\end{array}$ \\
\hline Intercept & $\begin{array}{c}-1.09 * * \\
(0.21)\end{array}$ & $\begin{array}{l}0.94 * * \\
(0.27)\end{array}$ & $\begin{array}{c}-0.81^{* *} \\
(0.22)\end{array}$ & $\begin{array}{c}0.24 \\
(0.31)\end{array}$ & $\begin{array}{c}-0.15 \\
(0.41)\end{array}$ & $\begin{array}{c}1.65^{* *} \\
(0.49)\end{array}$ & $\begin{array}{c}0.28 \\
(0.46)\end{array}$ & $\begin{array}{c}0.36 \\
(0.57)\end{array}$ \\
\hline$N$ & & & & & & & & \\
\hline$A I C$ & 34 & & 31 & & & 1.0 & 12 & \\
\hline
\end{tabular}

Notes: ${ }^{*} \mathrm{p} \leq 0.10 ;{ }^{* *} \mathrm{p} \leq 0.05$. Standard errors in parentheses. Cost is modelled with a dummy for abstention as dependent variable; utility with a dummy variable for a 'yes' vote as dependent variable.

there was a positive link between voting 'yes' and Ireland's economic prospects. Those who expect a 'no' vote to disimprove Irish' economic prospects were more likely to vote 'yes' in 2008 and in 2009 those who expect a 'yes' vote to improve Irish' economic prospects were strongly inclined to support the Treaty. Those who thought economic prospects would worsen were slightly more likely to vote 'no'. While the change in sign is a direct result of the changed question wording, there is also a clearly visible change in effect magnitude, which shows the impact of the changed economic context in which the referendum took place. ${ }^{6}$ Figure 1 provides a visualisation of the main effect, showing how pocketbook voting (comparing the 'own economic situation is good' to the 'own economic situation is bad' column) mattered clearly in 2008, but much less so in 2009, where the two columns are near-identical. For sociotropic voting, on the other hand (comparing the rows of the figure), we do see strong effects in both years, but particularly in 2009 . This provides strong and statistically significant support for $\mathrm{H} 4$.
While the effect was significant in 2008, the magnitude of the coefficient is statistically significantly larger in 2009. This implies the economic panic argument-that voters switched their vote between 2008 and 2009 because of the GFC, has some weight to it, evidence again that context is crucial in determining the economic motivations of vote choice. More interestingly, sociotropic utility is consistently important in shaping referendum vote choice, in line with the literature that sociotropic utility is a more consistent predictor of vote choice.

\section{Conclusion}

The two Irish referendums on the Lisbon Treaty, either side of the onset of the GFC, offer an ideal opportunity to explore economic voting in referendums and to establish whether and in what circumstances sociotropic or egocentric utility drives vote choice. Our study shows that voter's economic perceptions mattered in both referendums. In both referendums, sociotropic motivations

\footnotetext{
${ }^{6}$ In the Appendix in Table A1 we provide results using conventional logistic regressions instead of the model specification proposed by Sattler and Urpelainen (2012). Overall results are similar, but for the impact of economic prospects, we do not find as strong results in 2008-we nevertheless confirm the stark difference between 2008 and 2009, in the same direction.
} 


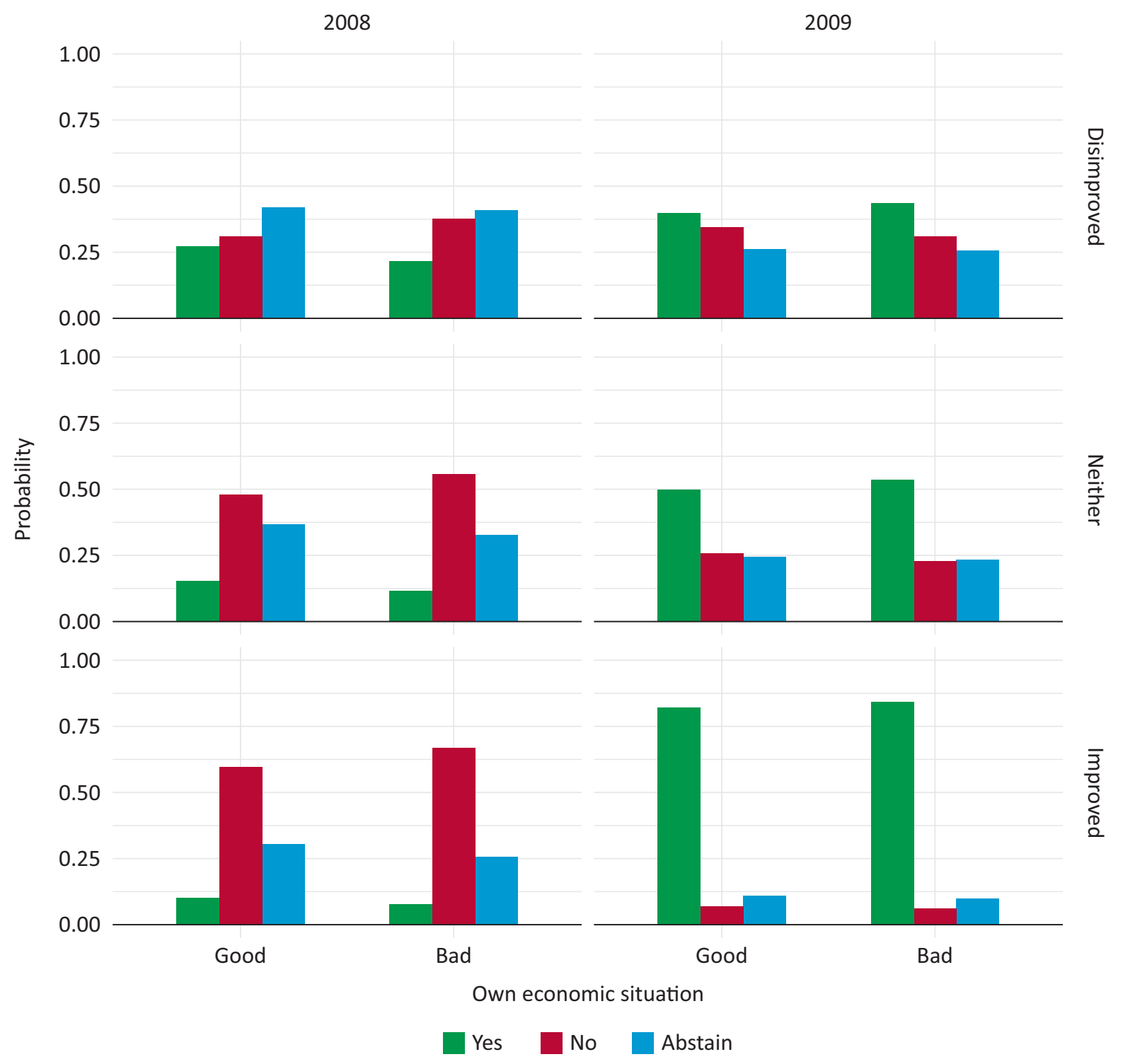

Figure 1. Predicted probabilities based on Model 6 and Model 8 , keeping all other independent variables at the mode for categorical variables, based on the 2008 data set, and at zero for the standardized scale variables.

were important, with its effect larger in the 2009 referendum post the onset of the GFC. Meanwhile, egocentric utility was more important in 2008 when particular groups, adversely impact by globalization, and voters who perceived the EU as not having a positive influence on their personal economic situation were more likely to vote against the Treaty. In 2009 however, the egocentric economic evaluation was not a significant factor and while certain groups of voters were still more likely to vote against the Lisbon Treaty, thus offering some support for the utilitarian view, egocentric considerations were less important in 2009 compared with 2008. This highlights the important role of context-in a different economic environment, voters' economic calculations shift, where in times of crisis, sociotropic became even more important and egocentric considerations less so.

While our study of two subsequent referendums on the same Treaty, in the same country, under the same government, provides a unique opportunity to investigate this dynamic, we recognize the second referendum might have been too soon after the onset of the economic crisis. The role of the EU in the resolution to the crisis only became visible in the years after the referendum. We recognize that some scholars suggest that the initial years of the GFC did not have a significant impact on Euroscepticism but rather the latter years.

\section{Acknowledgments}

The authors thank Todd Donovan, Mark Franklin and the anonymous reviewers for their excellent feedback. We are also appreciative of comments to an earlier version of the article presented at the seminar series of the School of Politics and International Relations, University College Dublin. 


\section{Conflict of Interests}

The authors declare no conflict of interests.

\section{References}

Anderson, C. (2000). Economic voting and political context: A comparative perspective. Electoral Studies, 19(2), 151-170.

Aylott, N. (2005). Lessons learned, lessons forgotten: The Swedish referendum on EMU of September 2003. Government and Opposition, 40(4), 540-564.

Bartkowska, M., \& Tiemann, G. (2015). The impact of economic perceptions on voting behaviour in European parliamentary elections. Journal of Common Market Studies, 53(2), 201-217.

Bjørklund, T. (2009). The surge of referendums and the new politics approach. In M. Setälä \& T. Schiller (Eds.), Referendums and representative democracy: Responsiveness, accountability and deliberation (pp. 117-136). Abingdon: Routledge Chapman \& Hall.

Central Statistics Office. (2010a). Live Register January 2010 (No. 20/2010). Dublin: Central Statistics Office. Retrieved from https://www.cso.ie/en/ media/csoie/releasespublications/documents/ labourmarket/2010/Ireg_jan2010.pdf

Central Statistics Office. (2010b). Quarterly National Accounts, Quarter 3 2010. (No. 233/2010). Dublin: Central Statistics Office. Retrieved from https:// www.cso.ie/en/media/csoie/releasespublications/ documents/economy/2010/qna_q32010.pdf, accessed 10 June 2019.

Clarke, H. D., Goodwin, M., \& Whiteley, P. (2017). Brexit: Why Britain voted to leave the European Union. Cambridge: Cambridge University Press.

Clarke, H. D., Kornberg, A., \& Stewart, M. (2004). Referendum voting as political choice: The case of Québec. British Journal of Political Science, 34(2), 345-355.

Curtice, J. (2014). The score at half time: Trends in support for independence. Edinburgh: ScotCentre Social Research. Retrieved from http://www.natcen.ac.uk/ media/270726/SSA-13-The-Score-At-Half-Time.pdf

Darcy, R., \& Laver, M. (1990). Referendum dynamics and the Irish divorce amendment. Public Opinion Quarterly, 54(1), 1-20.

Dassonneville, R., \& Lewis-Beck, M. S. (2014). Macroeconomics, economic crisis and electoral outcomes: A national European pool. Acta Politica, 49(4), 372-394.

Doyle, O., \& Fidirmuc, J. (2006). Who favours enlargement? Determinants of support for EU membership in the candidate countries' referenda. European Journal of Political Economy, 22(2), 520-543.

Eichenberg, R. C., \& Dalton, R. J. (2007). Post-Maastricht blues: The transformation of citizen support for European integration, 1973-2004. Acta Politica, 42(2), 128-152.

Elkink, J. A., \& Sinnott, R. (2015). Political knowledge and campaign effects in the 2008 Irish referendum on the Lisbon Treaty. Electoral Studies, 38, 217-225.

Evans, G., \& Anderson, R. (2006). The political conditioning of economic perceptions. Journal of Politics, 68(1), 194-207. https://doi.org/10.1111/j.14682508.2006.00380.x

Fraile, M., \& Lewis-Beck, M. S. (2014). Economic vote instability: Endogeneity or restricted variance? Spanish panel evidence from 2008 and 2011. European Journal of Political Research, 53(1), 160-179.

Franklin, M. (2002). Learning from the Danish case: A comment on Palle Svensson's critique of the Franklin thesis. European Journal of Political Research, 41(6), 751-757.

Franklin, M., Marsh, M., \& Wleizen, C. (1994). Attitudes towards Europe and referendum votes: A response to Siune and Svensson. Electoral Studies, 13(2), 117-121.

Gabel, M. (1998a). Economic integration and mass politics: Market liberalization and public attitudes in the European Union. American Journal of Political Science, 42(3), 936-953.

Gabel, M. (1998b). Public support for European integration: An empirical test of five theories. Journal of Politics, 60(2), 333-354.

Gabel, M., \& Palmer, H. D. (1995). Understanding variation in public support for European integration. European Journal of Political Research, 27(1), 3-19.

Gabel, M., \& Whitten, G. D. (1997). Economic conditions, economic perceptions, and public support for European integration, 1973-2004. Political Behaviour, 19(1), 81-96.

Garry, J., Marsh, M., \& Sinnott, R. (2005). 'Second-order' versus 'Issue-voting' effects in EU referendums. European Union Politics, 6(2), 201-221.

Gomez, R. (2015). The economy strikes back: Support for the EU during the Great Recession. Journal of Common Market Studies, 53(3), 577-592.

Hicks, R., Milner, H. V., \& Tingley, D. (2014). Trade policy, economic interests, and party politics in a developing country: The political economy of CAFTA-DR. International Studies Quarterly, 58(1), 106-117.

Hobolt, S. B. (2005). When Europe matters: The impact of political information on voting behaviour in EU referendums. Journal of Elections, Public Opinion, and Parties, 15(1), 85-109.

Hobolt, S. B. (2009). Europe in question: Referendums on European integration. Oxford: Oxford University Press.

Hobolt, S. B., \& de Vries, C. (2016). Public support for European integration. Annual Review of Political Science, 19, 413-432.

Hooghe, L., \& Marks, G. (2004). Does identity or economic rationality drive public opinion on European integration. Political Science and Politics, 37(3), 415-420.

Jupille, J., \& Leblang, D. (2007). Voting for change: Cal- 
culation, community, and Euro referendums. International Organization, 61(4), 763-782.

Kiewiet, D. R. (1983). Macroeconomics and micropolitics. Chicago, MI: University of Chicago Press.

Kiewiet, D. R., \& Lewis-Beck, M. S. (2011). No man is an island: Self-interest, the public interest, and sociotropic voting. Critical Review, 23(3), 303-319.

Kinder, D. R., \& Kiewiet, D. R. (1979). Economic discontent and political behavior: The role of personal grievances and collective economic judgments in congressional voting. American Journal of Political Science, 23(3), 495-527.

Kriesi, H., Grande, E., Lachat, R., Dolezal, M., Bornschier, S., \& Frey, T. (Eds.). (2008). West European politics in an age of globalization. Cambridge: Cambridge University Press.

LeDuc, L. (2002a). Opinion change and voting behaviour in referendums. European Journal of Political Research, 41(6), 711-729.

LeDuc, L. (2002b). Referendums and initiatives: The politics of direct democracy. In Comparing democracies 2: New challenges in the study of elections and voting (pp. 70-87). London: Sage Publications.

LeDuc, L. (2015). Referendums and deliberative democracy. Electoral Studies, 38(1), 139-148.

Lewis-Beck, M. S. (1988). Economics and the American voter: Past, present, future. Political Behaviour, 10(1), 5-21.

Lewis-Beck, M. S., Nadeau, R., \& Elias, A. (2008). Economics, party, and the vote: Causality issues and panel data. American Journal of Political Science, 52(1), 84-95.

Lewis-Beck, M. S., \& Stegmaier, M. (2000). Economic determinants of electoral outcomes. Annual Review of Political Science, 3(1), 183-219.

Lewis-Beck, M. S., \& Stegmaier, M. (2013). The VPfunction revisited: A survey of the literature on vote and popularity functions after over 40 years. Public Choice, 157(3/4), 267-285.

Lewis-Beck, M. S., Stubager, R., \& Nadeau, R. (2013). The Kramer problem: Micro-macro resolution with a Danish pool. Electoral Studies, 32(3), 500-505.

McLaren, L. (2002). Public support for the European Union: Cost/benefit analysis or perceived cultural threat? Journal of Politics, 64(2), 551-566.

Melzer, A. H., \& Richard, S. F. (1981). A rational theory on the size of government. Journal of Political Economy, 89(5), 914-927.

Nadeau, R., Martin, P., \& Blais, A. (1999). Attitude towards risk-taking and individual choice in the Québec referendum on sovereignty. British Journal of Political Science, 29(3), 523-539.

Nannestad, P., \& Paldam, M. (1995). It's the government's fault: A cross-section study of economic voting in Denmark 1990/1993. European Journal of Political Research, 28(1), 33-62.

Nannestad, P., \& Paldam, M. (1997). From the pocketbook of the welfare man: A pooled cross-section study of economic voting in Denmark 1986-1992. British Journal of Political Science, 27(1), 111-155.

O'Brien, R. M. (2007). A caution against rules of thumb for variance inflation factors. Quality \& Quantity, 41(5), 673-690.

O'Mahony, J. (2009). Ireland's EU referendum experience. Irish Political Studies, 24(4), 429-446.

Okolikj, M., \& Quinlan, S. (2016). Context matters: Economic voting in the 2009 and 2014 European parliament elections. Politics and Governance, 4(1), 145-166.

Pammett, J. H., \& LeDuc, L. (2001). Sovereignty, leadership, and voting in the Québec referendums. Electoral Studies, 20(2), 265-280.

Powell, G. B., \& Whitten, G. D. (1993). A cross-national analysis of economic voting: Taking account of the political context. American Journal of Political Science, 37(2), 391-414.

Quinlan, S. (2009). The Lisbon Treaty referendum 2008. Irish Political Studies, 24(1), 107-121.

Quinlan, S. (2010). The 2009 European parliament election in Ireland. Irish Political Studies, 25(2), 289-301.

Quinlan, S. (2012). The Lisbon experience in Ireland: 'No' in 2008 but 'yes' in 2009: How and why? Irish Political Studies, 27(1), 139-153.

Qvortrup, M. (2018). Introduction: Theory, practice and history. In M. Qvortrup (Ed.), Referendums around the world. Basingstoke: Palgrave \& MacMillan.

Rose, R., \& Borz, G. (2016). Static and dynamic views of European integration. Journal of Common Market Studies, 54(2), 370-387.

Sanders, M. S. (1998). Unified models of turnout and vote choice for two-candidate and three-candidate elections. Political Analysis, 7(1), 89-115.

Sattler, T., \& Urpelainen, J. (2012). Explaining public support for international integration: How do national conditions and treaty characteristics interact with individual beliefs? Journal of Politics, 74(4), 1108-1124.

Singer, M. (2011). Who says 'It's the economy'? Crossnational and cross-individual variation in the salience of economic performance. Comparative Political Studies, 44(3), 284-312.

Sinnott, R. (2005). Funding for referendum campaigns: Equal or equitable? In Dissecting Irish politics: Essays in honour of Brian Farrell. Dublin: University College Dublin Press.

Sinnott, R., \& Elkink, J. A. (2010). Attitudes and behaviour in the second referendum on the Treaty of Lisbon 2009 (Report for the Department of Foreign Affairs). Dublin: UCD Geary Institute and University College Dublin. Retrieved from http://www.ucd.ie/ t4cms/Attitudes\%20and\%20Behaviour\%20in\% 20the\%20Second\%20Referendum\%20on\%20the\% 20Treaty\%20of\%20Lisbon.pdf

Sinnott, R., Elkink, J. A., O’Rourke, K., \& McBride, J. (2009). Attitudes and behaviour in the referendum on the Treaty of Lisbon. Dublin: UCD Geary Institute 
and University College Dublin. Retrieved from http://www.joselkink.net/files/UCD\%20Geary\% 20Institute\%20report\%20-\%20DFA\%20March\% 202009\%20-\%20final\%20version.pdf

Soroka, S. (2006). Good news and bad news: Asymmetric responses to economic information. Journal of Politics, 68(2), 372-385.

Svensson, P. (2002). Five Danish referendums on the European Community and Union: A critical assessment of the Franklin Thesis. European Journal of Political Research, 41(6), 733-750.

Talving, L. (2017). The electoral consequences of austerity: Economic policy voting in Europe in times of crisis. West European Politics, 40(3), 560-583.

Teney, C., Lacewell, O. P., \& De Wilde, P. (2014). Winners and losers of globalization in Europe: Attitudes and ideologies. European Political Science Review, 6(4),
575-595.

Tucker, J. A., Pacek, A. C., \& Berinsky, A. J. (2002). Transitional winners and losers: Attitudes toward EU membership in post-communist countries. American Journal of Political Science, 46(3), 557-571.

Tverdova, Y. V., \& Anderson, C. J. (2004). Choosing the West? Referendum choices on EU membership in east-central Europe. Electoral Studies, 23(2), 185-208.

van der Eijk, C., Franklin, M., \& Marsh, M. (1996). What voters teach us about Europe-wide elections: What Europe-wide elections teach us about voters. Electoral Studies, 15(2), 149-166.

Wlezien, C., Franklin, M., \& Twiggs, D. (1997). Economic perceptions and the vote choice: Disentangling the endogeneity. Political Behaviour, 19(1), 7-17.

\section{About the Authors}

Johan A. Elkink is Associate Professor in Social Science Research Methods at University College Dublin. He specialises in quantitative methods in political science, in particular spatial econometrics and network statistics. Besides applications in voting behaviour in referendums and national elections, he wrote on the international diffusion of democracy and the evolution of personalist regimes. His work appeared, among other outlets, in the Journal of Politics, Comparative Political Studies, European Journal of Political Research and Electoral Studies.

Stephen Quinlan is Senior Researcher at the GESIS Leibniz Institute for the Social Sciences, Mannheim, and Project Manager of the Comparative Study of Electoral Systems (CSES) Project which focuses on electoral behaviour cross-nationally. His research centres on electoral behaviour in comparative perspective, including elections, parties, referendums, opinion polls, social media, and forecasting. His work has appeared in Electoral Studies, Information Communication and Society, Politics and Governance and Irish Political Studies.

Richard Sinnott is Professor Emeritus of Political Science in University College Dublin. He was awarded a Research Fellowship from the ESRI in 1976 to study for a PhD at Georgetown University. He has held research fellowships at the European University Institute, Harvard University, Nuffield College Oxford and Waseda University. A leading scholar on European referendums, turnout, and Irish voting behaviour, his work appeared in numerous outlets, including British Journal of Political Science, European Journal of Political Research, and European Union Politics. 


\section{Appendix}

This Appendix provides additional robustness checks evaluating our main findings. While we opt for a regression model that simultaneously incorporates the decision to vote and the vote choice, which we consider mutually dependent decisions, the more conventional approach is to run separate binomial regressions with either turnout (or abstention) or vote as dependent variable. Table A1 provides these in the form of logistic regressions, explaining abstention and the 'yes' vote, respectively, for the 2008 and 2009 referendums. Furthermore, Table A1 replicates the full model specification for 2009 in the article, Model 8, with one additional variable-attitude towards further European integration-which was not available in the 2008 data set, and therefore left out of the article.

A further extension evaluates more in depth the interaction between party preference and sociotropic or pocketbook voting, using interaction variables between all party dummies and all economic variables in the model (cf. Hicks, Milner, \& Tingley, 2014). These results are presented in Table A2. While results are weaker due to the many variables in the model, overall findings remain the same, and we find limited evidence of interaction effects. Party preference does affect sociotropic voting in the 2009 referendum, but not to such an extent that it changes our main findings-even for those parties where sociotropic voting is weakest (Fine Gael, Labour), the effect is still positive and statistically significant.

Table A1. Logistic regressions explaining vote choice in the 2009 Lisbon referendum in Ireland, evaluating motivations behind economic voting.

\begin{tabular}{|c|c|c|c|c|c|c|}
\hline & \multirow{2}{*}{\multicolumn{2}{|c|}{$\frac{2009}{\text { Model } 8 \text { with unification }}$}} & \multicolumn{2}{|c|}{2008} & \multicolumn{2}{|c|}{2009} \\
\hline & & & \multirow{2}{*}{$\begin{array}{c}\text { Model 9a } \\
\text { Abstention }\end{array}$} & \multirow{2}{*}{$\begin{array}{l}\text { Model 9b } \\
\text { Yes vote }\end{array}$} & \multirow{2}{*}{$\begin{array}{l}\text { Model 10a } \\
\text { Abstention }\end{array}$} & \multirow{2}{*}{$\begin{array}{l}\text { Model 10b } \\
\text { Yes vote }\end{array}$} \\
\hline & Cost & Utility & & & & \\
\hline \multirow[t]{2}{*}{ Female } & & -0.16 & & 0.10 & & -0.10 \\
\hline & & $(0.18)$ & & $(0.15)$ & & $(0.26)$ \\
\hline \multirow[t]{2}{*}{ Age 18-24 } & 0.48 & -0.62 & $1.58^{* *}$ & -0.56 & $1.23^{* *}$ & -0.70 \\
\hline & $(0.30)$ & $(0.40)$ & $(0.25)$ & $(0.34)$ & $(0.41)$ & $(0.58)$ \\
\hline \multirow[t]{2}{*}{ Age 25-34 } & 0.24 & -0.47 & $1.28 * *$ & $-0.67 * *$ & $0.76^{* *}$ & -0.23 \\
\hline & $(0.28)$ & $(0.34)$ & $(0.22)$ & $(0.28)$ & $(0.38)$ & $(0.49)$ \\
\hline \multirow[t]{2}{*}{ Age $35-49$} & -0.01 & -0.26 & $0.74 * *$ & $-0.42^{*}$ & 0.24 & -0.53 \\
\hline & $(0.28)$ & $(0.33)$ & $(0.22)$ & $(0.25)$ & $(0.37)$ & $(0.45)$ \\
\hline \multirow[t]{2}{*}{ Age 50-64 } & -0.16 & -0.33 & 0.31 & -0.30 & 0.08 & -0.61 \\
\hline & $(0.31)$ & $(0.34)$ & $(0.22)$ & $(0.25)$ & $(0.38)$ & $(0.47)$ \\
\hline \multirow[t]{2}{*}{ Lower middle class } & -0.40 & 0.02 & -0.10 & -0.21 & -0.51 & -0.29 \\
\hline & $(0.26)$ & $(0.31)$ & $(0.19)$ & $(0.23)$ & $(0.34)$ & $(0.42)$ \\
\hline \multirow[t]{2}{*}{ Skilled working class } & -0.26 & -0.33 & -0.27 & $-0.47^{*}$ & -0.07 & -0.70 \\
\hline & $(0.28)$ & $(0.34)$ & $(0.21)$ & $(0.27)$ & $(0.36)$ & $(0.46)$ \\
\hline \multirow[t]{2}{*}{ Unskilled working class } & -0.39 & -0.14 & -0.14 & $-0.48^{*}$ & -0.49 & -0.37 \\
\hline & $(0.28)$ & $(0.34)$ & $(0.22)$ & $(0.29)$ & $(0.37)$ & $(0.46)$ \\
\hline \multirow[t]{2}{*}{ Farmer } & $-1.35 *$ & 0.65 & -0.46 & 0.12 & $-1.50 * *$ & 0.80 \\
\hline & $(0.71)$ & $(0.54)$ & $(0.29)$ & $(0.35)$ & $(0.64)$ & $(0.70)$ \\
\hline \multirow[t]{2}{*}{ Secondary education } & -0.23 & 0.04 & 0.22 & -0.14 & -0.63 & -0.10 \\
\hline & $(0.29)$ & $(0.38)$ & $(0.24)$ & $(0.31)$ & $(0.40)$ & $(0.55)$ \\
\hline \multirow[t]{2}{*}{ Third level education } & -0.12 & 0.13 & 0.25 & -0.03 & -0.54 & 0.08 \\
\hline & $(0.32)$ & $(0.42)$ & $(0.27)$ & $(0.35)$ & $(0.45)$ & $(0.61)$ \\
\hline \multirow[t]{2}{*}{ Objective knowl. EU } & 0.06 & 0.14 & $-0.37 * *$ & $0.37 * *$ & -0.07 & 0.12 \\
\hline & $(0.16)$ & $(0.20)$ & $(0.13)$ & $(0.18)$ & $(0.22)$ & $(0.27)$ \\
\hline \multirow[t]{2}{*}{ Subjective knowl. EU } & -0.06 & 0.21 & $-0.30 * *$ & 0.04 & -0.38 & 0.54 \\
\hline & $(0.22)$ & $(0.25)$ & $(0.15)$ & $(0.20)$ & $(0.28)$ & $(0.35)$ \\
\hline \multirow[t]{2}{*}{ Subjective knowl. Treaty } & -1.11 & -0.15 & $-1.71 * *$ & $0.71 * *$ & $-1.55^{* *}$ & $-0.90 * *$ \\
\hline & $(0.22)$ & $(0.26)$ & $(0.15)$ & $(0.20)$ & $(0.28)$ & $(0.37)$ \\
\hline \multirow[t]{2}{*}{ Own econ. situation bad } & & 0.27 & & $-0.49 * *$ & & 0.07 \\
\hline & & $(0.20)$ & & $(0.20)$ & & $(0.27)$ \\
\hline \multirow[t]{2}{*}{ Econ. prosp. improved } & & $1.60 * *$ & & -0.46 & & $2.17^{* *}$ \\
\hline & & $(0.22)$ & & $(0.35)$ & & $(0.31)$ \\
\hline \multirow[t]{2}{*}{ Econ. prosp. disimproved } & & -0.52 & & $1.24 * *$ & & -0.62 \\
\hline & & $(0.32)$ & & $(0.17)$ & & $(0.46)$ \\
\hline
\end{tabular}


Table A1. (Cont.) Logistic regressions explaining vote choice in the 2009 Lisbon referendum in Ireland, evaluating motivations behind economic voting.

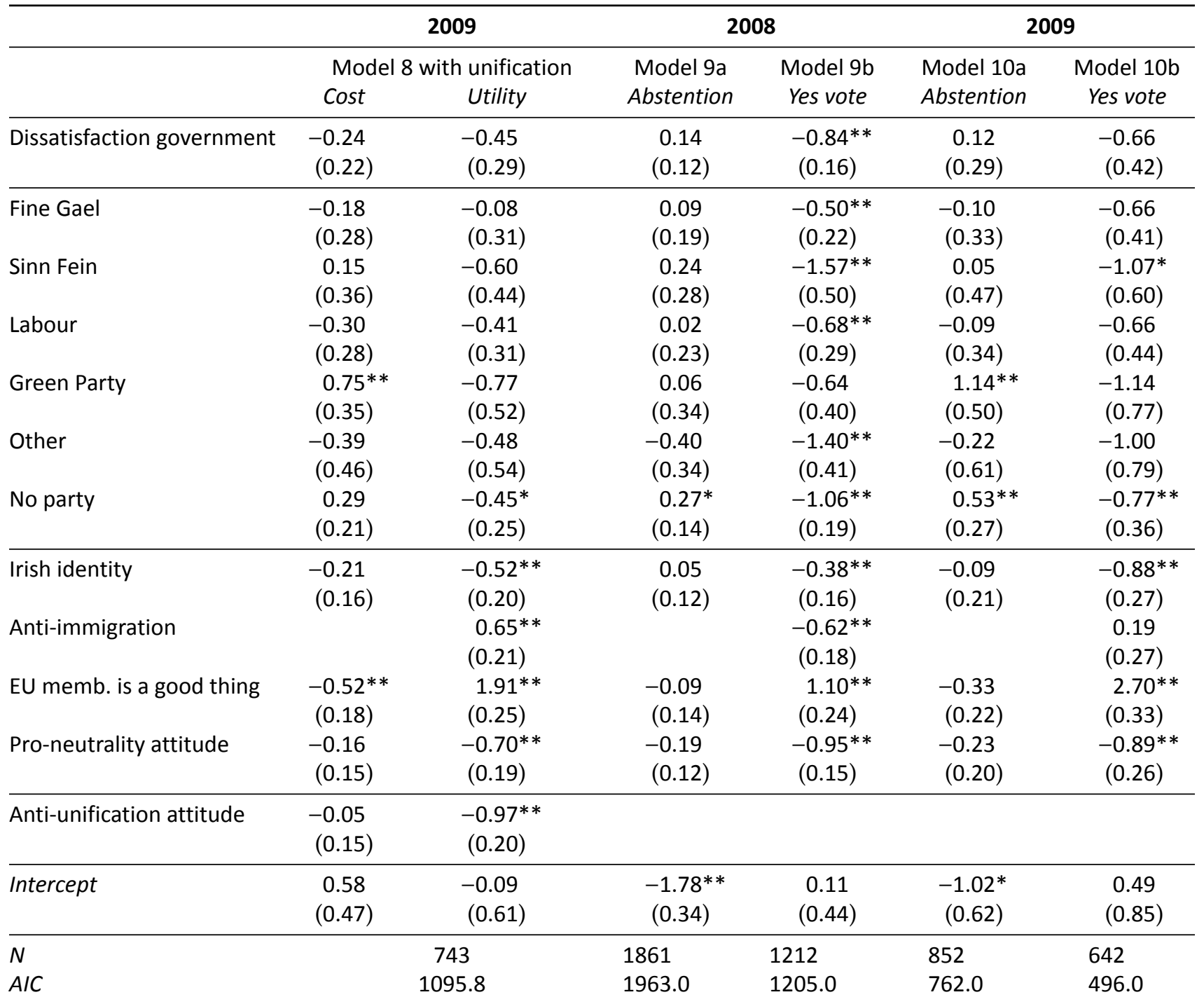

Notes: ${ }^{*} \mathrm{p} \leq 0.10 ; * * \mathrm{p} \leq 0.05$. Standard errors in parentheses. For the expanded Model 8 , the logistic random utility model of Sattler and Urpelainen (2012) is used, with the attitude against further integration added as an additional control, which is unavailable in the 2008 data. For the remaining model, regular logistic regression is used, separately modelling abstention and vote choice.

Table A2. Logistic regressions explaining vote choice in the 2008 and 2009 Lisbon referendums in Ireland, including interactions between party choice and economic variables.

\begin{tabular}{|c|c|c|c|c|}
\hline & \multicolumn{2}{|c|}{2008} & \multicolumn{2}{|c|}{2009} \\
\hline & \multicolumn{2}{|c|}{ Model 11} & \multicolumn{2}{|c|}{ Model 12} \\
\hline & Cost & Utility & Cost & Utility \\
\hline Female & & $\begin{array}{c}-0.01 \\
(0.10)\end{array}$ & & $\begin{array}{c}-0.18 \\
(0.17)\end{array}$ \\
\hline Age 18-24 & $\begin{array}{l}0.93^{* *} \\
(0.16)\end{array}$ & $\begin{array}{c}-0.36 \\
(0.23)\end{array}$ & $\begin{array}{c}0.53^{*} \\
(0.28)\end{array}$ & $\begin{array}{c}-0.68^{*} \\
(0.38)\end{array}$ \\
\hline Age 25-34 & $\begin{array}{l}0.89 * * \\
(0.15)\end{array}$ & $\begin{array}{c}-0.61^{* *} \\
(0.20)\end{array}$ & $\begin{array}{c}0.26 \\
(0.27)\end{array}$ & $\begin{array}{c}-0.39 \\
(0.32)\end{array}$ \\
\hline Age 35-49 & $\begin{array}{l}0.52^{* *} \\
(0.15)\end{array}$ & $\begin{array}{c}-0.29 \\
(0.18)\end{array}$ & $\begin{array}{c}-0.02 \\
(0.27)\end{array}$ & $\begin{array}{c}-0.35 \\
(0.31)\end{array}$ \\
\hline Age 50-64 & $\begin{array}{c}0.20 \\
(0.16)\end{array}$ & $\begin{array}{c}-0.18 \\
(0.18)\end{array}$ & $\begin{array}{c}-0.20 \\
(0.29)\end{array}$ & $\begin{array}{r}-0.43 \\
(0.32)\end{array}$ \\
\hline
\end{tabular}


Table A2. (Cont.) Logistic regressions explaining vote choice in the 2008 and 2009 Lisbon referendums in Ireland, including interactions between party choice and economic variables.

\begin{tabular}{|c|c|c|c|c|}
\hline & & & & \\
\hline & & & & \\
\hline & Cost & Utility & Cost & Utility \\
\hline Lower middle class & $\begin{array}{c}-0.07 \\
(0.12)\end{array}$ & $\begin{array}{c}-0.09 \\
(0.16)\end{array}$ & $\begin{array}{c}-0.49 * \\
(0.26)\end{array}$ & $\begin{array}{c}-0.16 \\
(0.30)\end{array}$ \\
\hline Skilled working class & $\begin{array}{c}-0.13 \\
(0.13)\end{array}$ & $\begin{array}{c}-0.32 * \\
(0.19)\end{array}$ & $\begin{array}{c}-0.24 \\
(0.27)\end{array}$ & $\begin{array}{c}-0.37 \\
(0.33)\end{array}$ \\
\hline Unskilled working class & $\begin{array}{c}0.00 \\
(0.14)\end{array}$ & $\begin{array}{c}-0.30 \\
(0.20)\end{array}$ & $\begin{array}{c}-0.41 \\
(0.27)\end{array}$ & $\begin{array}{c}-0.17 \\
(0.34)\end{array}$ \\
\hline Farmer & $\begin{array}{c}-0.22 \\
(0.19)\end{array}$ & $\begin{array}{c}0.04 \\
(0.25)\end{array}$ & $\begin{array}{c}-0.98^{*} \\
(0.51)\end{array}$ & $\begin{array}{c}0.55 \\
(0.50)\end{array}$ \\
\hline Secondary education & $\begin{array}{c}0.17 \\
(0.15)\end{array}$ & $\begin{array}{c}-0.06 \\
(0.22)\end{array}$ & $\begin{array}{c}-0.15 \\
(0.28)\end{array}$ & $\begin{array}{c}-0.24 \\
(0.37)\end{array}$ \\
\hline Third level education & $\begin{array}{c}0.13 \\
(0.16)\end{array}$ & $\begin{array}{c}-0.04 \\
(0.25)\end{array}$ & $\begin{array}{c}-0.12 \\
(0.32)\end{array}$ & $\begin{array}{c}-0.14 \\
(0.41)\end{array}$ \\
\hline Objective knowl. EU & $\begin{array}{c}-0.30 * * \\
(0.08)\end{array}$ & $\begin{array}{c}0.19 \\
(0.13)\end{array}$ & $\begin{array}{c}0.11 \\
(0.15)\end{array}$ & $\begin{array}{c}0.11 \\
(0.19)\end{array}$ \\
\hline Subjective knowl. EU & $\begin{array}{c}-0.16^{*} \\
(0.09)\end{array}$ & $\begin{array}{c}-0.04 \\
(0.14)\end{array}$ & $\begin{array}{c}-0.14 \\
(0.21)\end{array}$ & $\begin{array}{c}0.25 \\
(0.24)\end{array}$ \\
\hline Subjective knowl. Treaty & $\begin{array}{c}-1.11^{* *} \\
(0.10)\end{array}$ & $\begin{array}{l}0.50^{* *} \\
(0.14) \\
\end{array}$ & $\begin{array}{c}-1.16^{* *} \\
(0.20)\end{array}$ & $\begin{array}{c}-0.26 \\
(0.24)\end{array}$ \\
\hline Own econ. situation bad & & $\begin{array}{c}-0.26 \\
(0.22)\end{array}$ & & $\begin{array}{c}0.02 \\
(0.40)\end{array}$ \\
\hline × Fine Gael & & $\begin{array}{c}-0.04 \\
(0.37)\end{array}$ & & $\begin{array}{c}-0.42 \\
(0.57)\end{array}$ \\
\hline$\times$ Sinn Fein & & $\begin{array}{c}-0.35 \\
(0.54)\end{array}$ & & $\begin{array}{c}0.45 \\
(0.86)\end{array}$ \\
\hline$\times$ Labour & & $\begin{array}{c}-0.11 \\
(0.45)\end{array}$ & & $\begin{array}{c}-0.03 \\
(0.61)\end{array}$ \\
\hline$\times$ Green Party & & $\begin{array}{c}0.86 \\
(0.82)\end{array}$ & & $\begin{array}{c}0.59 \\
(1.03)\end{array}$ \\
\hline$\times$ Other & & $\begin{array}{c}0.25 \\
(0.59)\end{array}$ & & $\begin{array}{c}1.47 \\
(0.19)\end{array}$ \\
\hline$\times$ No party & & $\begin{array}{c}-0.20 \\
(0.29)\end{array}$ & & $\begin{array}{c}-0.34 \\
(0.49)\end{array}$ \\
\hline Econ. prosp. improved & & $\begin{array}{c}-0.62 \\
(0.41)\end{array}$ & & $\begin{array}{l}2.40^{* *} \\
(0.47)\end{array}$ \\
\hline$\times$ Fine Gael & & $\begin{array}{c}-0.24 \\
(0.63)\end{array}$ & & $\begin{array}{c}-1.43^{* *} \\
(0.65)\end{array}$ \\
\hline$\times$ Sinn Fein & & $\begin{array}{c}1.39 \\
(1.56)\end{array}$ & & $\begin{array}{c}-1.44 \\
(1.01)\end{array}$ \\
\hline$\times$ Labour & & $\begin{array}{c}0.39 \\
(0.67)\end{array}$ & & $\begin{array}{c}-1.21^{*} \\
(0.68)\end{array}$ \\
\hline$\times$ Green Party & & $\begin{array}{c}1.38 \\
(1.73)\end{array}$ & & $\begin{array}{c}-0.07 \\
(1.25)\end{array}$ \\
\hline$\times$ Other & & $\begin{array}{c}0.81 \\
(1.01)\end{array}$ & & $\begin{array}{c}0.94 \\
(1.59)\end{array}$ \\
\hline$\times$ No party & & $\begin{array}{c}0.18 \\
(0.58)\end{array}$ & & $\begin{array}{c}-0.96 \\
(0.60)\end{array}$ \\
\hline
\end{tabular}


Table A2. (Cont.) Logistic regressions explaining vote choice in the 2008 and 2009 Lisbon referendums in Ireland, including interactions between party choice and economic variables.

\begin{tabular}{|c|c|c|c|c|}
\hline & \multicolumn{2}{|c|}{2008} & \multicolumn{2}{|c|}{2009} \\
\hline & \multicolumn{2}{|c|}{ Model 11} & \multicolumn{2}{|c|}{ Model 12} \\
\hline & Cost & Utility & Cost & Utility \\
\hline \multirow[t]{2}{*}{ Econ. prosp. disimproved } & & $0.87 * *$ & & -0.03 \\
\hline & & $(0.19)$ & & $(0.73)$ \\
\hline \multirow[t]{2}{*}{$\times$ Fine Gael } & & 0.25 & & -0.23 \\
\hline & & $(0.35)$ & & $(0.98)$ \\
\hline \multirow[t]{2}{*}{$\times$ Sinn Fein } & & $-1.72 * *$ & & -1.03 \\
\hline & & $(0.62)$ & & $(1.21)$ \\
\hline \multirow[t]{2}{*}{$\times$ Labour } & & 0.04 & & 0.60 \\
\hline & & $(0.51)$ & & $(0.96)$ \\
\hline \multirow[t]{2}{*}{$\times$ Green Party } & & 0.20 & & -1.41 \\
\hline & & $(0.69)$ & & $(2.25)$ \\
\hline \multirow[t]{2}{*}{$\times$ Other } & & $-1.59 * *$ & & 0.61 \\
\hline & & $(0.62)$ & & $(1.29)$ \\
\hline \multirow[t]{2}{*}{$\times$ No party } & & -0.16 & & $-1.71 *$ \\
\hline & & $(0.28)$ & & $(1.00)$ \\
\hline \multirow[t]{2}{*}{ Dissatisfaction government } & $0.15^{* *}$ & $-0.55^{* *}$ & -0.18 & -0.34 \\
\hline & $(0.07)$ & $(0.11)$ & $(0.21)$ & $(0.28)$ \\
\hline \multirow[t]{2}{*}{ Fine Gael } & 0.09 & -0.34 & -0.23 & 0.43 \\
\hline & $(0.13)$ & $(0.22)$ & $(0.26)$ & $(0.47)$ \\
\hline \multirow[t]{2}{*}{ Sinn Fein } & 0.28 & -0.41 & -0.09 & 0.61 \\
\hline & $(0.18)$ & $(0.39)$ & $(0.35)$ & $(0.68)$ \\
\hline \multirow[t]{2}{*}{ Labour } & 0.06 & $-0.44^{*}$ & -0.38 & -0.33 \\
\hline & $(0.15)$ & $(0.26)$ & $(0.27)$ & $(0.53)$ \\
\hline \multirow[t]{2}{*}{ Green Party } & -0.08 & $-0.65^{*}$ & $0.80 * *$ & -1.07 \\
\hline & $(0.23)$ & $(0.34)$ & $(0.39)$ & $(0.75)$ \\
\hline \multirow[t]{2}{*}{ Other } & -0.17 & -0.50 & -0.20 & $-2.06^{*}$ \\
\hline & $(0.23)$ & $(0.44)$ & $(0.43)$ & $(1.22)$ \\
\hline \multirow[t]{2}{*}{ No party } & $0.25 * *$ & $-0.68 * *$ & 0.16 & -0.38 \\
\hline & $(0.09)$ & $(0.17)$ & $(0.20)$ & $(0.36)$ \\
\hline \multirow[t]{2}{*}{ Irish identity } & 0.06 & $-0.24 * *$ & -0.18 & $-0.56 * *$ \\
\hline & $(0.07)$ & $(0.11)$ & $(0.15)$ & $(0.19)$ \\
\hline \multirow[t]{2}{*}{ Anti-immigration } & & $-0.39 * *$ & & 0.25 \\
\hline & & $(0.11)$ & & $(0.19)$ \\
\hline \multirow[t]{2}{*}{ EU memb. is a good thing } & $-0.32 * *$ & $0.72 * *$ & $-0.37 * *$ & $1.88^{* *}$ \\
\hline & $(0.08)$ & $(0.16)$ & $(0.16)$ & $(0.23)$ \\
\hline \multirow[t]{2}{*}{ Pro-neutrality attitude } & 0.10 & $-0.64 * *$ & $-0.23^{*}$ & $-0.75^{* *}$ \\
\hline & $(0.07)$ & $(0.10)$ & $(0.14)$ & $(0.18)$ \\
\hline \multirow[t]{2}{*}{ Intercept } & $-0.80 * *$ & 0.17 & 0.43 & 0.28 \\
\hline & $(0.22)$ & $(0.32)$ & $(0.46)$ & $(0.61)$ \\
\hline$N$ & \multicolumn{2}{|c|}{1804} & \multicolumn{2}{|c|}{811} \\
\hline$A I C$ & & & & \\
\hline
\end{tabular}

Notes: ${ }^{*} p \leq 0.10 ;{ }^{* *} p \leq 0.05$. Standard errors in parentheses. Cost is modelled with a dummy for abstention as the dependent variable; utility with a dummy variable for a 'yes' vote as dependent variable.

\section{References}

Hicks, R., Milner, H. V., \& Tingley, D. (2014). Trade policy, economic interests, and party politics in a developing country: The political economy of CAFTA-DR. International Studies Quarterly, 58(1), 106-117.

Sattler, T., \& Urpelainen, J. (2012). Explaining public support for international integration: How do national conditions and treaty characteristics interact with individual beliefs? Journal of Politics, 74(4), 1108-1124. 